\title{
FDI \& Institutional Quality: Empirical Evidence from India
}

\author{
Leena Ajit Kaushal \\ Management Development Institute Gurgaon, India
}

\section{Keywords}

FDI, India, Institutional Quality, EPU, BIT, GMM, Gravity Model

\begin{abstract}
The study investigates the impact of India's institutional quality on FDI inflows using panel data of the top 15 investing nations over the period 2008-2018. The study employs the augmented gravity model to identify FDI inflow determinants in India. The empirical results confirm that institutional quality has a positive impact on FDI inflows in India. The improved institutional quality and macroeconomic factors have played a vital role in attracting FDI in India despite BIT terminations. The study suggests that India must further strategize enhancing human capital and propose liberal labor policies facilitating FDI inflows equally in the manufacturing sector, promoting exports.
\end{abstract}

\section{Introduction}

The association between institutions and FDI inflows have received significant attention in the recent past. With liberal policy frameworks becoming commonplace and losing some of their traditional power, countries have been focusing more on the governance and regulatory factors to improve their competitiveness in attracting FDI. The macroeconomic determinants remain the key, but institutions now play a more prominent role (North,1994). Foreign investors significantly consider institutional quality before investing in the host nation; hence they have become more critical than the cultural and cognitive variables in formulating international strategies. FDI literature significantly emphasizes the need for a quality institutional framework, especially for the developing nations, to attract more FDI flows (Uddin et al., 2019). Institutional and regulatory quality refers to the ability of the government to formulate and implement sound policies and regulations that permit and promote private sector development by placing uniform rules of economic engagement. As a matter of fact, realizing the importance of Institutional quality, developing nations have been significantly promoting liberal and conducive investment regimes to attract more FDI over the recent past.

FDI is an important source of private external finance promoting economic development in emerging nations. In 2018, the Asian region alone had adopted thirty-two new policy measures related to liberalization, promotion, and facilitation of FDI vis-a-vis two restrictive regulations. On the contrary, the developed world introduced twenty-one investment policy measures to reinforce restrictive regulations than seven favoring investments. Asian economies experienced a substantial $2 \%$ y-o-y growth in foreign direct investment (FDI) over the period of study (WIR, 2019). Though the global FDI inflows in India declined from $3.16 \%$ to $2.82 \%$; yet India consistently ranks among the top 5 developing nations receiving maximum FDI. Across the region, FDI growth has been more pronounced in China, Hong Kong, Singapore and Indonesia compared to India with a $10.5 \%$ decline over the period. Statistics show wider disparities across the globe and among developing Asian economies. Foreign investors prefer locations that offer the best economic and institutional facilities (Dunning, 1998). Studies suggest that institutional factors such as political stability, the rule of law attracting FDI (Akisik, 2020), uncertainty in economic policies and reforms (Tam, 2018), and ease of doing business (Hossain et al., 2018) significantly influence multinational corporations (MNCs) investment decisions. Investors prefer to wait and watch during high economic uncertainty instead of investing in the host country, mainly because these long-run commitments are costly to reverse (Canh et .al, 2020). A conducive business environment enables business conduction, whereas an adverse business environment and regulations hinder the starting and operation of businesses (Liu et al., 2021).

Over the years, India has liberalized its national FDI policy and implemented several institutional reforms to draw more FDI enabling country's growth. FDI cap has been reduced in many sectors, such as multi-brand retail and insurance, besides introducing GST and the Insolvency and Bankruptcy Code, 2016 to attract foreign investors to establish operations in India. India has also been targeting governance 
factors such as Economic Policy uncertainty (EPU), ease of doing business (EOBD), and labor reforms to improve its competitiveness. Studies highlight that time taken by the governments to formulate and implement new policies is the prime cause of uncertainty in the host nation's business environment (Zhang et al., 2015).

The present study employs an augmented gravity model to study the impact of institutional and regulatory quality on FDI inflow in India from top 15 investing nations. The study essentially estimates the impact of domestic EPU, EODB, and BITs on FDI inflows from 2008-2018. Indian government has taken numerous policy initiatives to boost FDI inflows. The last decade witnessed numerous economic and political turbulences, both at global and domestic front, ranging from the global financial crisis in 2008, Indian policy paralysis in 2011-12 resulting in high EPU, introduction of new FDI reforms, mainly entry focused regulations (automatic FDI approval procedure, ease of doing business), and replacing investor-centric 2003 Model BIT with a State-centric model in 2015 resulting in termination over 50 BITs and the most recent Brexit and US trade war. India's attractiveness as an investment destination has increased in the past, along with its bargaining power. Reducing EPU and disbanding FIPB (Foreign Investment Promotion Board) to improve further ease of doing business has been strongly emphasized by the Indian policymakers to foster a favorable investment climate. However, with the new BIT regime, it would be critical for India to generate innovative ideas to draw an adequate legal framework beneficial to all stakeholders. BITs offering investor protection is critical for ensuring FDI inflows unless the nations offer a stable political and transparent legislative and judicial environment for foreign investors (Busse et al., 2010).

There is a growing body of literature investigating the link between institutional factors and FDI inflows. However, most studies are regional, investigating the Asia-pacific region, OECD nations, developing nations but very few concerning individual nations, particularly India. Due to the ongoing pandemic and US-China trade war, developing Asian economies, particularly India, Bangladesh, and Vietnam, compete to attract most relocating MNCs operations due to the global turbulences ${ }^{1}$. The persistent nature of the FDI inflow requires a dynamic panel estimation technique (Singhania \& Saini, 2021). The present study employs system GMM method of Arellano and Bond (1991) to investigate the dynamic nature of the link between institutional factors and FDI inflows in India. The terms policy uncertainty, economic policy uncertainty, and political uncertainty are used interchangeably in the study. The remainder of this study is organized as follows. The following section reviews the literature on the determinants of FDI. The methodology and data are presented in Section 3, while Section 4 discusses the empirical results and section 5 concludes.

\section{Literature Review}

Institutions comprises of humanly devised rules that structure political, economic, and social issues (North, 1994). The formal and informal rules aim to create order and reduce uncertainty in the nation for different players and economic factors to interact and maximize gains. Along with the standard economic constraints, markets with good quality institutions affect the profitability and feasibility of economic activities by reducing transaction and production costs.

Conventionally, researchers focused on economic determinants such as market size, population and GDP per capita as the key explanatory variables influencing FDI; however, its argued that the economic considerations only come into full play when an enabling FDI policy framework is in place (Mallampally \& Sauvant,1999). Over the past two decades, developing nations have liberalized national policies to attract FDI by relaxing rules concerning market entry and foreign ownership, enhancing treatment standards for foreign firms, and improving markets' functioning. The past studies show that liberal FDI policies attract investors but do not guarantee investments (Rodríguez-Pose \& Cols, 2017)), leading to vast differences in investment volume across nations. Besides considering the state-of-the-art FDI policy frameworks, MNCs willing to invest increasingly gauge host countries' macroeconomic stability and institutional predictability. Studies suggest that good institutional factors compared to purely economic factors play an essential role in attracting FDI in emerging nations (Sabir et al., 2019).

${ }^{1}$ https://www.vietnam-briefing.com/news/relocating-production-comparing-vietnam-and-its-peers.html/ 
The relationship between FDI and institutions relies on the economic foundation of cost minimization (Nunnenkamp, 2002). The host country's institutions and government policies impact foreign investors' profitability through varied cost implications, including transportation, production, operation, and manufacturing (North,1994). Good quality institutions reduce the cost of doing business by providing a risk-free business environment and significantly minimizing expenses (Sabir et al., 2019). The association between institutional factors and FDI attractiveness is commonly described through its positive or negative influence on FDI inflows. Investors consider a range of business facilitating institutional determinants such as corruption (Nguyen,2015), domestic economic policy uncertainty (Canh et al.,2020), the rule of law (Zhu et al., 2019), ease of starting and running a business (Mahuni \& Bonga, 2017), BITs (Liu et al., 2021besides the macroeconomic determinants related to the size of markets for goods and services in terms of GDP per capita (Khan et al., 2020), economic growth (Blonigen \& Piger, 2014), productive cost advantage in terms of labor cost (Dorakh, 2020) and financial openness (Gaies \& Nabi, 2019) among others. The present study mainly investigates the impact of select instructional factors, EPU, Ease of starting business and BITs on FDI inflows which have been the major concern for Indian policymakers in the recent past.

\section{Select Variables of Interest}

\subsection{Economic Policy Uncertainty (EPU)}

The uncertainty concerning the host nation's fiscal or monetary policy, banking sector reforms, and insolvency regulations worsen the EPU index (Choi et al., 2021). Ensuring macroeconomic stability and institutional predictability is the crucial tool for policymakers targeting substantial FDI inflows. However, since 2015, several facilitative measures to attract more FDI, such as GST, Insolvency \& Bankruptcy code and labor reforms, came into existence. Since then, EPU has reported a consistent rise (Fig.1), contrary to the rising global policy uncertainty. India has thus fostered a healthy investment climate enabling consistency in actual policy with forwarding guidance to reduce EPU (Economic Survey 2019).

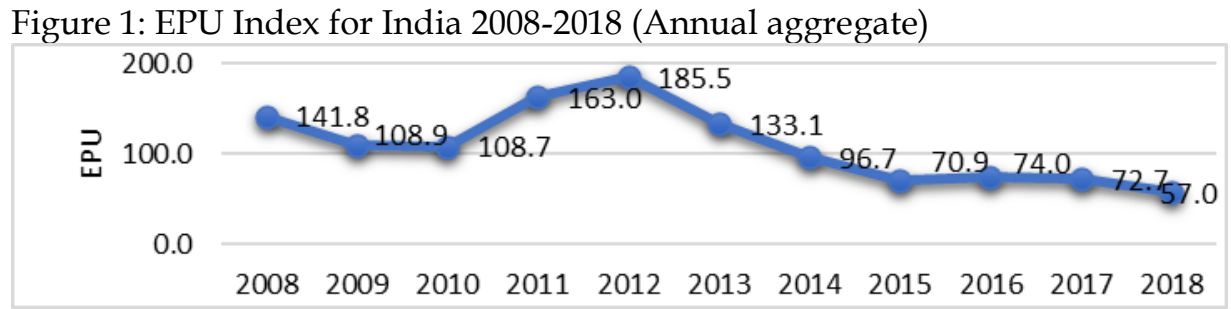

Source: www.policyuncertainty.com

\section{Ease of starting a Business(EOSB)}

The ease of starting a Business is a vital entry barrier to establish a foreign subsidiary by multinational firms (Mahuni \& Bonga, 2017). The indicator measures paid-in minimum capital requirement, time, cost, and the number of procedures required for a small to medium-sized limited liability company to formally operate the business in an economy (World Bank, 2018). Over the last decade, the Indian government has made significant progress in streamlining the application processes via merging various documentations into a single form, online registration portals and automatic FDI approvals.

Figure 2: Ease of Starting a business Score (2008-2018)

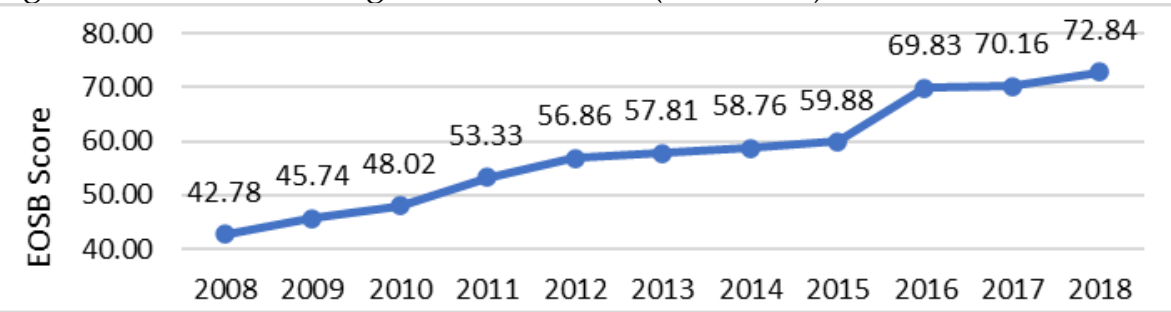

Source: World Bank 


\subsection{Bilateral investment treaties (BITs)}

BITs provide foreign investors the right against the host state during sudden changes in law or any other measures that essentially devalue or expropriate foreign investments. In the recent past, India faced numerous arbitrations claims under its BITs, which prompted the shift from an overly investor-friendly approach to a slightly protectionist approach. India adopted a new BIT model in 2015 and terminated BITs with over 66 countries, including $22 \mathrm{EU}$ nations. To balance investment protection with the state's right to regulate, India needs to evolve its BIT practice based on the twin framework of the international rule of law and embedded liberalism (Ranjan, 2019).

\section{Research Methodology}

The standard gravity model of international trade (Tinbergen, 1962) is widely used to investigate trade flow between countries. The GDP of a nation acts as a pull factor stimulating trade, whereas the distance between them is a push factor constraining trade. However, more recently, the augmented gravity models have found a broad empirical fit to predict FDI flows and stocks between partner countries (Welfens \& Baier, 2018). The standard gravity model augmented with numerous policy and nonpolicy factors (Falk, 2016) examines their relevance, enabling trade and investment between partners. The present study uses an augmented gravity model to identify the determinants of India's FDI inflows from top sourcing nations, focusing on institutional quality estimated by domestic EPU and EODB as a proxy for regulatory environment quality and BITs as a proxy for the strong international rule of law. The study employs FDI flows instead of FDI stock to ensure consistency in measuring the dependent variable. Measurement of FDI stock flowing from different investing countries tends to be heterogeneous with many zeroes and negative values. Sparse data related to India's FDI stock from its investing partners also makes it appropriate to rely on FDI flows for our study's estimation procedure. The study uses a double $\log$ model for analyzing FDI determinants in India. The study uses a double log model to analyze FDI determinants in India. The dependent variable is expressed as $\log (1+\mathrm{FDI})$ to accommodate the periods with zero value into the double log model. Equation 1 represents the static gravity framework:

Equation 1:

$$
\begin{aligned}
& \ln \left(F D I_{i j t}\right)=\alpha+\beta_{1} \ln \left(\left|G D P p c_{i t}-G D P p c_{j t}\right|\right)+\beta_{2} \ln \left(F D I o p_{i j t}\right)+\beta_{3} B I T_{i j t}+\beta_{4} \ln \left(E O S B_{j t}\right) \\
& +\beta_{5} \ln \left(E P U_{j t}\right)+\beta_{6} \ln \left(\text { LaborCost }_{j t}\right)+\beta_{7} \ln \left(\text { GDPsum }_{i j t}\right)+\beta_{8}(\text { PopGr })_{j t}+\epsilon_{i j t}
\end{aligned}
$$

Equation 2 represents dynamic panel by incorporating the lagged value of $\log (1+\mathrm{FDI})$. The dynamic equation is specified as follows:

$$
\begin{aligned}
& \text { Equation } 2 \\
& \begin{array}{c}
\ln \left(F^{F D I_{i j t}}\right)=\alpha+\beta_{1} \ln \left(F D I(-1)_{i j t}\right)+\beta_{2} \ln \left(\mid G_{\text {GPpc }}-\text { GDPpc }_{j t} \mid\right)+\beta_{3}\left(\text { FDIop }_{i j t}\right)+\beta_{4} \ln \left(\text { EOSB }_{j t}\right) \\
+\beta_{5} \ln \left(E P U_{j t}\right)+\beta_{6} \ln \left(\text { LaborCost }_{j t}\right)+\beta_{7} \ln \left(\text { GDPsum }_{i j t}\right)+\beta_{8}(\text { PopGr })_{j t}+\beta_{9}(B I T)_{j t}+\epsilon_{i j t}
\end{array}
\end{aligned}
$$

Were,

$\mathrm{FDI}_{\mathrm{ijt}}$ is the FDI inflow from the source country $\mathrm{i}$ to the host country $\mathrm{j}$ during for year $\mathrm{t}$,

FDI $_{\mathrm{ijt}}(-1)$ is one-year lag of FDI from the source country $i$ to the host country $j$ for the year $t$,

$\mathrm{GDP}_{\text {it }}$ is the nominal GDP of the source country $\mathrm{i}$,

$\mathrm{GDP}_{\mathrm{jt}}$ is the nominal GDP of the host country $\mathrm{j}$ (India),

$\mathrm{GDPpc}_{i t}$ is the per capita GDP of the source country $i$,

$\mathrm{GDPpc}_{\mathrm{jt}}$ is the per capita GDP of the host country $\mathrm{j}$ (India)

FDIop $_{\mathrm{ijt}}$ is the financial openness of the host country $j$

BIT $_{\mathrm{ijt}}$ is the dummy variable taking value 1 if countries $\mathrm{i} \& \mathrm{j}$ have an active BIT in the year $\mathrm{t}, 0$ otherwise

PoPGrowth $\mathrm{j}_{\mathrm{t}}$ is the $\%$ change in population from period $t-1$ to period $t$ of the host country $j$

EaseofBusiness $\mathrm{j}_{\mathrm{t}}$ is the ease of starting business score of the host country $\mathrm{j}$ in the year $\mathrm{t}$

$E P U_{j t}$ is the economic policy uncertainty index value of the host country $j$ in the year $t$

LaborCostjt the share of labor income as a percentage of the nominal GDP of the host country $j$ for the year $t$ is used a proxy for labor cost

$i$ is the source of FDI inflows, $j$ is the host country into which FDI flows, $t$ is the time indicator (annual) and $\epsilon$ is the error term. 
The sum of the Gross Domestic Product of the host and source countries intends to capture the horizontal market size. The variable is expected to positively affect the dependent variable if the source country views the host as an extended market for its products and services, thus directing FDI. This variable's inclusion and coverage are similar to the variables found in several studies (Cieślik,2021).

The absolute difference in the GDP per capita between the home and the host nation helps measure the skill differential and captures the vertical FDI drive (Jang 2011). The variable's coefficient from the estimated model would either confirm the Linder hypothesis or the Heckscher-Ohlin (H-O) perspective. We expect a positive coefficient, confirming the $\mathrm{H}-\mathrm{O}$ theory asserting that countries benefit from their relative factor endowments.

Financial Openness of the host country $\mathrm{j}$ (India) is measured as the sum of FDI inflows and outflows as a percentage of the total GDP. Greater liberalization of foreign investment policies by the governing bodies should ideally result in a higher financial openness ratio. The variable is expected to exhibit a positive relationship with FDI inflows.

Bilateral Investment Treaties (BITs) are treated as a dummy variable and incorporated in the study. If the host country has an active treaty with the source country for the year $t$, the dummy is assigned the value 1, else 0 . The study by Banga (2003) suggests that BITs signed between developing Asian nations (including India) and the developed nations significantly impacted FDI inflow compared to BITSs entered with other developing nations during 1980 to 2000.

Population growth is considered a proxy for the availability of human capital in the host country. The increasing children to working adults' ratio and a fall in capital to labor ratio diverts household income from savings towards consumption besides pushing limited government resources towards health and education, compromising more productive enterprises Coale \& Hoover 1958). The host country's human capital plays a critical role in determining FDI inflows (Borensztein, 1998), but excessive population growth puts immense pressure on the available infrastructure. This may result in a low quality of available human capital, deterring investors from investing in the country. The variable will have a positive coefficient if the growing pool of available human capital attracts investors. However, beyond a certain limit, expansion in human capital negatively affects FDI (Abdouli \& Omri, 2021). The EODB score identifies the barriers to entry faced by investors to start a business in a foreign country. The score captures the number of required procedures a firm must undergo, the actual time required in business days to complete the formal procedures, and the total cost of complying with the regulatory procedures. A higher score indicates lower entry barriers; thus, we expect the variable to correlate with FDI inflow positively. Economic policy uncertainty is assessed using the news-based index constructed by Baker, Bloom \& Davis (2016). Lower policy uncertainty in the host country relative to the source countries positively affects FDI inflows into the host country (Nguyen et al., 2015). We expect the EPU index to have an inverse relationship with the dependent variable since policy uncertainties are detrimental to attract FDI. As a proxy for labor costs, the study includes labor income as a share of GDP estimated by the International Labor Organization. Labor income comprises of compensation of employees and income share of self-employed. Studies propose that labor market rigidity and strict employment protection, besides dampening MNCs' initial entry, also influence foreign firms' employment and production (Mina,2020).

The study estimates the impact of institutional factors, BITs, EPU, and EOSB on the FDI inflow from 15 top investing nations in India. As widely suggested in the literature the study employs static panel models the fixed effects (FE) and random effects (RE) specifications to evaluate the relationship between institutional factors \& FDI inflows (Asongu et al., 2018). FE model allows each cross-section to have its intercept and assumes similar slopes and constant variance across the various cross-sections. The specification is appropriate for analyzing specific entities such as countries, individuals, or firms. FE specification with 'within effect' estimates overcome the endogeneity problem, making it the most "simple and persuasive" econometric methodology (Vaisey \& Miles 2017). Hausman specification test selects between FE and RE models. Dynamic panel regression proposed by Arellano \& Bond (1991) is used to estimate the dynamic relationship between FDI inflows and regressors, including the lagged value of a dependent variable. The lagged dependent variable causing several econometric issues, including endogeneity, needs proper estimation to draw meaningful inferences. 


\section{Results And Discussion}

Before running the regression, the study conducted descriptive statistics and multicollinearity tests, summarized in Table (Appendix A). The findings are reported in Table 1.

Table 1: Panel Regression Findings

\begin{tabular}{|c|c|c|c|c|c|c|}
\hline & \multicolumn{2}{|l|}{ Random Effect } & \multicolumn{2}{|l|}{ Fixed Effect } & \multicolumn{2}{|l|}{ System GMM } \\
\hline & Coeff. & $\mathrm{p}$-value & Coeff. & p-value & Coeff. & p-value \\
\hline $\operatorname{lnFDI}_{\mathrm{ijt}}(-1)$ & - & - & - & - & $\begin{array}{l}0.164^{*} \\
(0.029)\end{array}$ & 0.000 \\
\hline $\operatorname{lnGDP} P_{\mathrm{ijt}} \mathrm{sum}$ & $\begin{array}{c}6.311 \\
(3.615)\end{array}$ & 0.225 & $\begin{array}{l}0.8321 \\
(6.015)\end{array}$ & 0.782 & $\begin{array}{c}5.193^{* *} \\
(2.3914\end{array}$ & 0.032 \\
\hline $\ln \left|\mathrm{GDP}_{\mathrm{it}}-\mathrm{GDP}_{\mathrm{jt}}\right|$ & $\begin{array}{l}0.521^{* *} \\
(0.234)\end{array}$ & 0.014 & $\begin{array}{l}1.835^{*} \\
(0.516)\end{array}$ & 0.004 & $\begin{array}{l}1.231^{* *} \\
(0.712)\end{array}$ & 0.025 \\
\hline FDIop $_{n j}$ & $\begin{array}{l}2^{27.353^{* *}} \\
(0.920)\end{array}$ & 0.020 & $\begin{array}{l}32.301^{* *} \\
(1.172)\end{array}$ & 0.023 & $\begin{array}{l}35.119^{*} \\
(6.271)\end{array}$ & 0.048 \\
\hline $\ln \mathrm{PoPGr}_{\mathrm{jt}}$ & $\begin{array}{l}-7.216^{\star * *} \\
(1.372)\end{array}$ & 0.000 & $\begin{array}{l}-12.421^{*} \\
(1.2829\end{array}$ & 0.000 & $\begin{array}{l}-7.930^{*} \\
(1.369)\end{array}$ & 0.003 \\
\hline $\mathrm{BIT}_{\mathrm{ijt}}$ & $\begin{array}{l}-0.1421 \\
(0.215)\end{array}$ & 0.429 & $\begin{array}{l}-0.087 \\
(0.253)\end{array}$ & 0.560 & $(2.724)^{-2.893}$ & 0.432 \\
\hline $\operatorname{lnEODB}$ & $\begin{array}{l}2.860^{* * *} \\
(1.620)\end{array}$ & 0.067 & $\begin{array}{l}3.284^{*} \\
(1.37) \\
\end{array}$ & 0.030 & $\begin{array}{l}3.392^{*} \\
(0.892)\end{array}$ & 0.000 \\
\hline $\operatorname{lnEPU}$ & $\begin{array}{c}-0.004 \\
(0.291)\end{array}$ & 0.982 & $\begin{array}{l}0.121 \\
(0.215) \\
\end{array}$ & 0.728 & $\begin{array}{l}0.229^{*} \\
(0.072) \\
\end{array}$ & 0.009 \\
\hline $\operatorname{lnLabCost} t_{j t}$ & $\begin{array}{l}-0.523 \\
(0.054\end{array}$ & 0.342 & $\begin{array}{l}-0.068^{*} \\
(0.061)\end{array}$ & 0.232 & $\begin{array}{l}-0.037^{* *} \\
(0.039)\end{array}$ & 0.034 \\
\hline Const. & $\begin{array}{c}12.943 \\
(19.298)\end{array}$ & 0.121 & $\begin{array}{c}16.673^{* *} \\
(19.123)\end{array}$ & 0.016 & $\begin{array}{l}24.823^{* *} \\
(27.204)\end{array}$ & 0.029 \\
\hline R-Square & 0.335 & & 0.371 & & & \\
\hline Hausman Test & Prob $>x^{2}$ & 0.000 & & & & \\
\hline $\begin{array}{ll}\text { Hansen } & \text { J- } \\
\text { Statistic } & \\
\end{array}$ & & & & & 12.210 & 0.260 \\
\hline $\begin{array}{l}\text { Arellano-Bond } \\
\mathrm{AR}(1)\end{array}$ & & & & & $\begin{array}{l}-1.932 \\
(0.010)\end{array}$ & \\
\hline $\begin{array}{l}\text { Arellano-Bond } \\
\mathrm{AR}(2)\end{array}$ & & & & & $\begin{array}{l}0.214 \\
(0.649)\end{array}$ & \\
\hline \multicolumn{2}{|c|}{ Wald test for Heteroscedasticity } & & & \multicolumn{3}{|c|}{ Prob $>x^{2}=0.000$} \\
\hline \multicolumn{2}{|c|}{ Wooldridge test for autocorrelation } & & & \multicolumn{3}{|c|}{ Prob $>F=0.0026$} \\
\hline
\end{tabular}

Note: * ${ }^{* *}, * * *$ indicate the statistical significance of the variable at 1 percent, 5 percent and 10 percent, respectively. All standard errors in parenthesis and p-values are robust for heteroscedasticity.

The study discusses the findings of dynamic two-step system GMM and FE specification.

Financial Openness measuring the impact of India's investment policies on FDI inflow is positive and consistently significant at a 5\% level across GMM \& FE models. In 2005, the Indian government substantially liberalized many sectors, allowing non-residents to take full ownership or raising participatory equity stakes across sectors. The pace of FDI reforms easing India's restrictive FDI rules further picked momentum since 2014 by introducing 37 reforms till date, such as replacing the Foreign Investment Promotion Board (FIPB) with the Foreign Investment Facilitation Portal (FIFP) to speed up the FDI inflow and increase the transparency in FDI approvals. The government further liberalized insurance, defence, railways, and retail sector regulations, among others, to expand the scope of investment.

The absolute difference between GDPs per capita is found positively significant across FE ( $1 \%$ level) GMM (5\% level) model. This implies that the service sector in India attracts FDI due to relative factor endowment. The service industry is built on professional training and requires a highly specialized workforce to operate effectively. The availability of a skilled labor force with high productivity and output 
results in better prospects for foreign investors. This aligns with the Heckscher-Ohlin hypothesis of countries effectively utilizing their relative factor endowments while engaging in the international markets. The Indian service sector has been the largest recipient of FDI over 2000-2020, significantly more than the manufacturing sector.

The impact of population growth was negative and highly significant (1\% level) across FE \& GMM specifications, contrary to the results reported by Bhasin \& Manocha (2016) for the period 2001-2012. Rapid population growth can raise alarming economic situations such as high unemployment, lack of infrastructure, and government inability to provide basic facilities such as health and education to the growing population (Musambachime, 1990). According to Barro (1996), the rising population diverts the nation's income towards ensuring capital for new workers rather than raising capital per worker, resulting in lower productivity among the labor force. However, countries may enhance their output per capita by increasing the capital per worker ratio to attract FDI. Research argues that sufficient absorptive capacity or a minimum level of human capital is required to boost growth via technology diffusion facilitated through FDI (Li \& Tanna,2019). BITs are found to be insignificant in determining FDI inflow into India across both specifications. During the study, total FDI inflows into India were almost evenly distributed between the years with an active BIT and years without a treaty.

Nevertheless, the total inflows in years with an active BIT were less than the total inflow in years without an active BIT by close to USD 40 billion, explaining the BIT's negative coefficient. 2016 onwards, India terminated BITs with over 50 nations, maintaining consistent FDI inflows. This explains the insignificance of BITs in Indian FDI. Thus, the present study (2008-2018) proposes that foreign investors have faith in the nations ' rule of law' because even after Bit's termination, FDI inflow exhibited a significant rise.

Economic Policy Uncertainty has a significant positive relationship (1\% level) with the dynamic panel model FDI inflows. The positive coefficient relates to the fact that from 2008 to 2018, India's policy uncertainty has fallen by a considerable margin, motivating investors to invest and start businesses in India. Investors also prefer simpler and shorter procedures for starting businesses. This is proven by the positive significance of ease of business score in driving FDI inflows across both specifications. The proxy for labor cost is negatively significant across FE (1\% level) and GMM (5\% level) models. The negative coefficient of labor cost indicates investors' preference for lower labor costs. Labor cost in India is significantly higher than other emerging nations and is thus a reason for losing substantial manufacturing FDI to our neighbors such as Sri Lanka and Bangladesh.

\section{Conclusion}

Foreign investors prefer locations that offer the best economic and institutional facilities. The host country's institutional quality and macroeconomic factors can thus attract foreign investments in the country. India's institutional quality in terms of the regulatory environment and the rule of law positively impacts FDI inflows throughout the study. Our analysis found that BITs are insignificant and tilted to the negative side in attracting FDI. This could be explained by the fact that India terminated multiple BITs in early 2016. However, despite the termination of treaties, FDI inflow in India has not been reduced, bestowing confidence in the nation's 'rule of law.' Coupled with the figures of FDI inflows from major nations with whom India has not signed any previous BITs, the total inflows for the years without any BITs edges out the years with BITs by almost USD 40 billion. Regulatory quality proxied by the ease of starting a business and the economic policy uncertainty index has significantly strengthened India's institutional quality attracting FDI inflows.

Foreign investors prefer locations that offer the best economic and institutional facilities. The host country's institutional quality and macroeconomic factors can thus attract foreign investments in the country. India's institutional quality in terms of the regulatory environment and the rule of law positively impacts FDI inflows throughout the study. Our analysis found that BITs are insignificant and tilted to the negative side in attracting FDI. This could be explained by the fact that India terminated multiple BITs in early 2016. However, despite the termination of treaties, FDI inflow in India has not been reduced, bestowing confidence in the nation's 'rule of law.' Coupled with the figures of FDI inflows from major nations with whom India has not signed any previous BITs, the total inflows for the years without any BITs edges out the years with BITs by almost USD 40 billion. Regulatory quality proxied by the ease of 
starting a business and the economic policy uncertainty index has significantly strengthened India's institutional quality attracting FDI inflows.

Throughout the study, the liberal FDI policies with greater openness and persistently improving institutional quality have attracted maximum FDI in the service sector based on the available skilled labor force. Since the early 20s, the service sector has been the largest recipient of investment in India. However, the high labor cost coupled with low productivity on account of the nation's rising population is the cause for low FDI in the manufacturing sector. The study indicates that high labor costs and stringent labor laws have been a significant barrier to FDI inflows, especially in manufacturing. Thus, the study recommends that India further strengthen its institutional quality to provide a business-friendly environment attracting more market-seeking (horizontal FDI) and efficiency-seeking (Vertical FDI) investments in the emerging Asian region. The recent modifications of Labor laws are the efforts made in the right direction to improve the institutional environment and attract more FDI across manufacturing and service sectors. BITs are one of the various factors that attract FDI and promote investors' confidence.

Nevertheless, an institutionally strong nation with sound economic policies and regulations certainly has a more prominent role in drawing FDI. Findings indicate that the Government of India has been successfully improving nations' institutional quality by offering sustained business reforms and a regulatory business environment with judicial evolution, thus attracting FDI despite the termination of BITs. However, enacting a robust domestic law with a strong dispute resolution mechanism, signalling investors protection in the absence of BITs, may further encourage FDI and is highly endorsed. The study further recommends that India focus on improving the quality of education and health services to strengthen its human capital. The equal distribution of education tends to impact per capita income in most countries positively. Thus, as the findings suggest, institutional reforms have successfully influenced FDI inflows in India; however, India must further strategize enhancing human capital and propose liberal labour policies facilitating FDI inflows equally in the manufacturing sector, promoting exports.

\section{References}

Abdouli, M., \& Omri, A. (2021). Exploring the nexus among FDI inflows, environmental quality, human capital, and economic growth in the Mediterranean region. Journal of the Knowledge Economy, 12(2), 788-810.

Akisik, O. (2020). The impact of financial development, IFRS, and rule of LAW on foreign investments: A crosscountry analysis. International Review of Economics \& Finance, 69, 815-838.

Arellano, M., \& Bond, S. (1991). Some tests of specification for panel data: Monte Carlo evidence and an application to employment equations. The review of economic studies, 58(2), 277-297.

Arita, S., \& Tanaka, K. (2013). FDI and investment barriers in developing economies (No. 431). Institute of Developing Economies, Japan External Trade Organization (JETRO).

Asongu, S., Akpan, U. S., \& Isihak, S. R. (2018). Determinants of foreign direct investment in fast-growing economies: evidence from the BRICS and MINT countries. Financial Innovation, 4(1), 1-17.

Baker, S. R., Bloom, N., \& Davis, S. J. (2016). Measuring economic policy uncertainty. The quarterly journal of economics, 131(4), 1593-1636.

Banga, R. (2003). Impact of government policies and investment agreements on FDI inflows (No. 116). working paper.

Barro, R. (1996). Health and economic growth. World Health Organization.

Bhasin, N., \& Manocha, R. (2016). Do bilateral investment treaties promote FDI inflows? Evidence from India. Vikalpa, 41(4), 275-287.

Blonigen, B. A., \& Piger, J. (2014). Determinants of foreign direct investment. Canadian Journal of Economics/Revue canadienne d'économique, 47(3), 775-812.

Borensztein, E., De Gregorio, J., \& Lee, J. W. (1998). How does foreign direct investment affect economic growth? Journal of international Economics, 45(1), 115-135.

Busse, M., Königer, J., \& Nunnenkamp, P. (2010). FDI promotion through bilateral investment treaties: more than a bit? Review of World Economics, 146(1), 147-177.

Canh, N. P., Binh, N. T., Thanh, S. D., \& Schinckus, C. (2020). Determinants of foreign direct investment inflows: The role of economic policy uncertainty. International Economics, 161, 159-172.

Choi, S., Furceri, D., \& Yoon, C. (2021). Policy uncertainty and foreign direct investment. Review of International Economics, 29(2), 195-227.

Cieślik, A. (2021). MNE activity in poland: Horizontal, vertical or both? Emerging Markets Finance and Trade, 57(2), 335-347.

Coale, A. J., \& Hoover, E. M. (2015). Population growth and economic development. Princeton University Press. 
Falk, M. (2016). A gravity model of foreign direct investment in the hospitality industry. Tourism Management, 55, 225-237.

Gaies, B., \& Nabi, M. S. (2019). Financial openness and growth in developing countries. Journal of Economic Integration, 34(3), 426-464.

Hossain, MT, Hassan, Z., Shafiq, S., \& Basit, A. (2018). Ease of Doing Business and Its Impact on Inward FDI. Indonesian Journal of Management and Business Economics, 1(1), 52-65.

Jang, Y. J. (2011). The impact of bilateral free trade agreements on bilateral foreign direct investment among developed countries. The World Economy, 34(9), 1628-1651.

Khan, H., Khan, S., \& Zuojun, F. (2020). Institutional quality and financial development: Evidence from developing and emerging economies. Global Business Review, 0972150919892366.

Lankes, H. P., \& Venables, A. J. (1996). Foreign direct investment in economic transition: the changing pattern of investments. Economics of Transition, 4(2), 331-347.

Lee, S. H., \& Song, S. 2012. Host country uncertainty, intraMNC production shifts, and subsidiary performance. Strategic Management Journal, 33: 1331-1340

Li, C., \& Tanna, S. (2019). The impact of foreign direct investment on productivity: new evidence for developing countries. Economic Modelling, 80, 453-466.

Liu, P., Lu, Y., Sheng, B., Das, K. C., \& Li, L. (2021). Can foreign direct investment promote BIT signing? Journal of Asian Economics, 75, 101324.

Mahuni, K., \& Bonga, W. G. (2017). Nexus between doing business indicators and foreign direct investment for Zimbabwe: A time series analysis. Dynamic Research Journals' Journal of Economics and Finance (DRJ-JEF), 2(2), 01-08.

Mallampally, P., \& Sauvant, K. P. (1999). Foreign direct investment in developing countries. Finance and Development, 36, 34-37.

Mina, W. (2020). Do GCC market-oriented labor policies encourage inward FDI flows? Research in International Business and Finance, 51, 101092.

MogesEbero, E., \& Begum, M. (2016). The desirability of doing business and flow of foreign direct investment nexus: the case of Ethiopia. world, 114, 37-81.

Musambachime, M. (1990). The impact of rapid population growth and economic decline on the quality of education: the case of Zambia.

Nguyen, T. V. H., \& Cao, T. H. V. (2015). The impact of institutional quality on foreign direct investment (FDI) inflows to Vietnam. EADN Working Papers, 86.

North, D. C. (1994). Economic performance through time. The American economic review, 84(3), 359-368.

Nunnenkamp, P. (2002). Determinants of FDI in developing countries: has globalization changed the rules of the game? (No. 1122). Kiel Working Paper.

Ranjan, P. (2019). India and bilateral investment treaties: refusal, acceptance, backlash. Oxford University Press.

Rodríguez-Pose, A., \& Cols, G. (2017). The determinants of foreign direct investment in sub-Saharan Africa: What role for governance? Regional Science Policy \& Practice, 9(2), 63-81.

Sabir, S., Rafique, A., \& Abbas, K. (2019). Institutions and FDI: evidence from developed and developing countries. Financial Innovation, 5(1), 1-20.

Singhania, M., \& Saini, N. (2021). Demystifying pollution haven hypothesis: Role of FDI. Journal of Business Research, 123, 516-528.

Uddin, M., Chowdhury, A., Zafar, S., Shafique, S., \& Liu, J. (2019). Institutional determinants of inward FDI: Evidence from Pakistan. International Business Review, 28(2), 344-358.

Vaisey, S., \& Miles, A. (2017). What you can-and can't-do with three-wave panel data. Sociological Methods \& Research, 46(1), 44-67.

Welfens, P. J., \& Baier, F. J. (2018). BREXIT and foreign direct investment: Key issues and new empirical findings. International Journal of Financial Studies, 6(2), 46.

WIR, 2019. Special Economic Zones, available at: https://unctad.org/system/files/officialdocument/wir2019_en.pdf

World Bank, 2018. India: Systematic country diagnostic realizing the promise of prosperity, Report no:126284-IN.

Zhang, G., Han, J., Pan, Z., \& Huang, H. (2015). Economic policy uncertainty and capital structure choice: Evidence from China. Economic Systems, 39(3), 439-457.

Zhu, J., Jia, F., \& Wu, H. (2019). Bankruptcy costs, economic policy uncertainty, and FDI entry and exit. Review of International Economics, 27(4), 1063-1080. 